\title{
Active Citizenship among Muslims in Sweden: \\ From Minority Politics to Political Candidacy
}

\author{
Johan Cato \& Jonas Otterbeck
}

\begin{abstract}
Islam and Muslims are hot topics in politics. Muslims engaged in politics are accused of wanting to turn Sweden into an Islamic state; others try to find parallels between the Christian groups of political parties and Muslim interests. The article discusses the development in recent decades when individuals and organizations with an Islamic agenda have become politically active citizens. It looks at the different stages of initial organization and lobbying, and later, cooperation with established political actors. Finally, it discusses the individual candidacies in the 2010 election of some individuals who emphasized their Muslim identity.
\end{abstract}

\footnotetext{
Some improvement in political life can be observed, more Muslims have been entrusted with political positions on both local and national level, and we hope to have even more on the national level in the next national elections... We [have] learned more about Swedish society and about how political organizations are structured and how they work; we have gained useful knowledge about Sweden and democracy. We strive to be Swedish Muslims. (blog of Muslim activist Mahmoud Aldebe, 2009)
}

In Sweden, Muslims have been engaged in active citizenship (as defined below) for decades, but on the periphery. Recently, however, politically active Muslims have caused debate and headlines. During the last election campaign in 2010, a couple of parliamentary candidates motivated their political commitment through their Islamic 
faith and their Muslim identity. Their suitability as politicians was called into question. This raises important questions about the conditions for political and active citizenship for Muslims in the Swedish context. ${ }^{1}$

While formal citizenship refers to membership in a political community, active citizenship is something that must be learned over time, according to Voet (1998). Its ideal form-full citizenship_implies that individuals are ready to take joint responsibility for policy decisions and have a willingness to accept political office, becoming capable, active citizens, not subordinate ones. Active citizenship can also be exercised outside national and municipal politics conducted through political parties, within civil society associations (Casanova 2001; Stoltz 2002).

People who perceive themselves as peripheral in society, which is common among immigrants and the children of immigrants, rarely engage in the national political parties. More often, they involve themselves in civil society associations (Stoltz 2002). It is therefore relevant to investigate how immigrants and their children engage themselves politically through civil society organizations and to see how these organizations relate to different levels of public governance (Odmalm 2007). A decade ago, José Casanova (2001) noted that religion had returned as an important civil society actor in several political arenas. The Nordic countries are considered among the most secular, but even there some researchers claim that change is taking place (cf. Martikainen in this volume). It is thus relevant to pay attention to religious lobbying groups and organizations active in civil society when describing active citizenship.

Our purpose in this article is to discuss the conditions and opportunities for those who seek to exercise active citizenship in their capacity as Muslims. We have concentrated on the active citizenship that has sprung from national umbrella organizations, being aware that much, if not most, Islamic active citizenship is performed locally (Otterbeck

\footnotetext{
1 The conditions for active citizenship are an expanding problem area in Islam-in-Europe research (Otterbeck 2010; Silvestri 2007; Statham et al. 2005;).
} 
2010). First, we will describe some important starting points for religious political participation in Sweden, then we look at Muslim political, civil society organizations. In addition, we will discuss their cooperation with established political parties and how these parties relate to Muslims. Finally, we will focus on a few cases in which Muslims seek positions in national politics. The aim is to illustrate empirically the conditions for active citizenship on a national level when performed from an Islamic, religious starting point. Further, we problematize the political interpretation of this active citizenship and show how both positive and negative attitudes are based on an understanding of Muslims as 'the excluded other'.

Fetzer and Soper (2005) argue that a country's political opportunity structures and political ideology make up the framework for active citizenship. A society's religiopolitical history, especially its church-state relations, tends to shape institutional structures and laws, but also the main ideology of the state. Political opportunity structures refer, for example, to the possibility of obtaining formal citizenship, principles of election participation, and the political distribution of power within the state. That it is possible to obtain Swedish citizenship after only five years' residence (and be an active citizen without citizenship) is of importance to Muslims since many are immigrants. Further, the changing role of the Swedish Church over time and the secularization of the Swedish state have had profound institutional and legal consequences. For example, the religious freedom law (1952), the recognition of the 'free churches' (Christian churches other than the Swedish Church) as qualified for state grants (1971), and the anti-discrimination laws that have gradually included religious affiliation as a recognized cause of discrimination (1976-2008), have shaped opportunities for Muslims' active citizenship.

The discussions of multiculturalism in Sweden took off in the early 1970s and led to the policy change often referred to as the minority policy decision (det minoritetspolitiska beslutet) from 1975 on equality, freedom and cultural cooperation between the majority, old minorities and new immigrant groups (Proposition 1975:26). The political idea behind the policy was that the right to cultural diversity would lead to understanding, 
cooperation and integration (mostly understood as assimilation), not to enclavism and cultural separateness. The policy decision implied an important ideological change. As part of this multicultural policy, the state and political parties sought partners among the Muslim population.

Allievi (2003) notes that, regardless of different strategies, political parties tend to assume that 'Muslim' is a relevant categorization of voters. It is common for Muslims to be ethnified in the public discourse, i.e. group characteristics such as cultural features are attributed to the Muslim population, even though it consists of individuals relating to diverse groups with different cultural, theological, national, linguistic and socioeconomic traditions and conditions (Roy 2004; in a Swedish context, see Otterbeck \& Bevelander 2006). In contrast, Silvestri (2007) suggests that the analysis of Muslim attitudes to active citizenship and Muslim patterns of mobilization in the public sphere should assume that Muslims are no different from other individuals. It is analytically unproductive to assume that all Muslims belong to a particular socio-political category.

\section{Sweden and Religion}

The Swedish state has far-reaching ambitions to organize social life. It is common for civil society agents to have an economic_-sometimes an organizational-cooperation with the state, the county administrative board, or municipality. Local projects, like dialogue groups or anti-racist initiatives, are often sponsored by one of these three levels of public governance, instead of being dependent on contributions from religious organizations, foundations or businesses, as they would be in many other countries (Berggren \& Trägårdh 2006). Civil society engagement is frequently channelled through social clubs linked to the labour movement or religious organizations that in turn often collaborate with the state. A large proportion of Swedes are members of a club. For example, $96 \%$ of people in the age group 25-64 belonged to a club in the year 2000; half of them claimed to be active (Lindgren 2008). Further, in 2008, more than 7.5 million people were members or active in a religious community that had a financial or organizational relationship with the state (the Swedish Church 2010; SST 2010). Either you are a member of the Swedish Church (approx. 6.7 million) or in a 
community financially supported by the state (see below about SST). Besides religious communities, there are several other associations motivated by a religious identity or ethos, like sub-groups of political parties, women's shelters, or temperance movements.

One main political structure for religious communities (not for the Swedish Church) is the financial assistance they can receive by organizing themselves according to the Swedish bureaucratic tradition of associations having annual meetings, statutes, a president, treasurer and membership records. In the 1960s, the state offered the 'free churches' the opportunity to get government subsidies, like other associations. After an intense debate marked by a historically grounded suspicion towards the Swedish Church and the state, representatives of the 'free churches' accepted the offer. The Commission for State Grants to Religious Communities (Samarbetsnämnden för statsbidrag till trossamfund: SST) was founded in 1971 (Ekström 2006). ${ }^{2}$ The commission operates under the Ministry of Culture. Catholic and Jewish communities were soon included as eligible, and in the mid-1970s Orthodox Christians and Muslims were offered support. These developments resulted in the policy decision on multiculturalism from 1975, mentioned above.

SST requires congregations to cooperate in national bodies. These have the task of allocating economic support calculated on the basis of the number $\operatorname{served}^{3}$ in congregational activities. Usually, financial support helps with paying the rent for premises, or fees for a religious expert, or salary for an administrator. SST offers courses in how to run an association according to Swedish administrative regulations and law (SST 2009).

\section{The Communities of Swedish Muslims}

There are six recognized Muslim national bodies eligible for support by the SST. The oldest is the United Islamic Communities in Sweden (Förenade Islamiska Församlingar

\footnotetext{
2 The commission changed its name in 2008 to 'Nämnden för statligt stöd till trossamfund' (still abbreviated SST). The English translation remains the same.

${ }^{3}$ Numbers include both paying members and those who use services offered by the congregations.
} 
i Sverige: FIFS) founded in 1974 to fill the need for a national umbrella organization for existing local congregations and to meet the requirements of SST to be eligible for state support. Consequently, FIFS coordinated congregations of different religious, ethnic, national and linguistic profiles. SST recognized FIFS in 1975. Other organizations have arisen as a result of disagreements, or when an ethnic or religious group has become large enough to become independent.

Sweden's Muslim Association (Sveriges Muslimska Förbund: SMF) was founded in 1982 and became eligible in 1983. The Union of Islamic Cultural Centres (Islamiska kulturcenterunionen: IKUS) was formed in 1984 and was recognized in 1987. Swedish Islamic Parishes (Svenska Islamiska Församlingar: SIF) was established in 2002 and was recognized immediately. Islamic Shia Communities in Sweden (Islamiska Shiasamfunden i Sverige: ISS) was founded in 1992 but first became eligible in 2008. The Bosnian Islamic Community (Bosniakiska islamiska samfundet: BIS) was founded in 1995 and was recognized in 2009.

FIFS, SMF and IKUS formed the Islamic Cooperation Council (IslamiskaSamarbetsrådet: IS) in 1988. The Council's role was to coordinate the national bodies and collaborate with SST. Today, all six national bodies are members of the IS.

In 2007, there were about 400,000 Muslims, with various backgrounds, in Sweden (Larsson \& Sander 2007). In 2012, it is likely to be 450,000. Through the IS the religious activities of some 110,000 Muslims are supported financially (SST 2010). SST estimates that it serves about $75 \%$ of all Muslim congregations (Otterbeck 2004). One effect of SST's support is that Swedish administrative traditions have spread among organized Muslims. The majority of the activities that the national bodies coordinate are ritual practices and courses teaching Islam (Otterbeck 1999). However, from a reading of FIFS's reporting on its activities, the organization, at least in part, may also be described as a channel for active citizenship on a national level: 
- FIFS cooperates with all recognized religious communities in Sweden through the framework of the SST as well as with individual religious communities [in] issues where they have common interests.

- FIFS is involved in religious dialogue, and particularly and preferably in peace issues.

- FIFS has a representative in the government's council for contacts with faith communities, led by the Minister of Culture. The Council addresses issues of diversity and integration.

- FIFS collaborates with the Swedish Civil Contingencies Agency (Myndigheten för samhällsberedskap och säkerhet). This has replaced the Swedish emergency management agency (Krisberedskapsmyndigheten) with which FIFS had extensive cooperation through the Religious Communities Emergency Management Agency (Trossamfundens krisberedskapsråd).

- FIFS collaborates with the legal, financial and administrative services agency (Kammarkollegiet) on issues related to the right to issue marriage certificates (vigselrätt). FIFS is open to projects and cooperation with the whole voluntary sector. (FIFS 2010, arranged in bullets by authors)

Thus, FIFS, like other national Islamic bodies, participates actively in society as a representative of Muslims in Sweden, sometimes sanctioned by the political system. The bodies are important platforms for individual Muslims' active citizenship.

\section{Political Communities of Muslims}

SST is an important structure for Muslim political communities. Contacts have been made between Muslim organization leaders from various traditions, the leaders have established an economic basis enabling them to engage on a different level from that on which activists can normally, and, not least, they have made contacts with other, nonMuslim, leaders and with political parties. Some have served as Muslim representatives in government councils and agencies.

Already in the 1970s the Muslim associations became aware of the importance and the 
possibility of acting politically. The first actions taken were to attempt to spread information about Islam orally and in writing (Otterbeck 2000) and to try to lobby politically to achieve specific minority rights, for the benefit of, for example, school children (halal food). In 1990, FIFS and SMF founded the Muslim Council of Sweden (Sveriges Muslimska Råd: SMR). It was assigned the task of representing the organizations before the authorities, disseminating information, participating in public debate, and setting up mosques and Islamic schools (Otterbeck 2000). Initially, SMR was led by Mahmoud Aldebe, who has become, over time, one of the few nationally known Muslims (see below). Today, SMR is described as a non-profit religious organization. It is not a member-based organization; rather, it consists of a union of organizations that includes, other than the founders, groups like Islamic Relief, a humanitarian organization. ${ }^{4}$

Initially, the strategy of the national bodies and SMR was to address particular questions related to Muslim minority issues, and to continue to work on lobbying. In a second phase, beginning in the mid-1990s, both SMR and the national bodies began to cultivate more lasting political contacts, and for example a long-standing partnership with the Christian, Social Democratic Brotherhood Movement (Broderskapsrörelsen) was launched (see below). A joint report from the Brotherhood Movement and SMR (1999) describes collaborative projects that, among other things, resulted in the Islamic Political Coalition (Politisk Islamisk Samling: PIS), formed to be a Muslim equivalent of the Brotherhood Movement. However, PIS never become a platform for political engagement. Instead, the Brotherhood Movement has moved towards an inclusive multi-faith policy.

A new, third phase in active citizenship began recently. Politically active Muslims are now seeking to be recognized as candidates within the established political parties (see below).

\footnotetext{
${ }^{4}$ At the annual meeting in 2010, SMF was excluded from SMR for repeated violations of SMR's constitution (SMR 2010).
} 


\section{Political Parties and the Understanding of Muslims}

We will now look into how the political activities of Muslim organizations are dealt with by the political elite, something that is of crucial importance, shaping the conditions of Muslim active citizenship. In addition to the political opportunities that were created for Muslims by SST, the Swedish authorities and political parties have used SST's network to find Muslims with which to cooperate. At the local level, SST's structures might not be as important, but in this article we concentrate on national politics.

Sweden's Christian Social Democrats, better known under the name 'the Brotherhood Movement', was founded in 1929 and is a self-governing organization within the Social Democratic Workers' Party (Lundberg 1988).

Cooperation between the Brotherhood Movement and SMR began in 1994 when SMR approached various parliamentary parties in an attempt to create opportunities for Muslims to engage politically. The SMR leadership argued that more Muslims ought to get involved in the established parties, instead of in organizations only focusing on 'Muslim issues'. The Social Democrats were in favour of substantial cooperation on a collective basis with Swedish Muslims, which may partly be explained by the fact that the party has a tradition of supporting various group interests. Responsibility for cooperation was delegated to the Brotherhood Movement. Other parties had a more cautious attitude, stressing that individual Muslims were welcome to get involved, but that more collective forms of collaboration were problematic as this could be perceived as Muslims being set aside from other members of the respective parties (Lagerlöf Nilsson \& Pauli 2005).

This collaboration has, for example, resulted in seminars on Islam and democracy and in leadership training courses for Muslim women held with the specific aim of creating a Muslim Social Democratic subsection (Johansson 2006). The Brotherhood Movement has collaborated with SMR (and the Jewish Council of Sweden) in trying to create a change in attitudes to religious slaughter, which remains forbidden in Sweden if 
performed without prior stunning, through an open letter to the Ministry of Agriculture, Food and Fisheries (Yttrande till Jordbruksdepartementet 2005).

At the organization's congress in 2007, it was unanimously decided that networks for people of other religious beliefs than the Christian should be created, which opened up opportunities for political cooperation with, and membership of, Muslim sympathizers (Sandström 2007). At the Congress in 2009, the Election Committee decided that a goal of the next Congress was to broaden the board by including Muslim representatives (Högfeldt 2009). The Socialist election defeat in 2010 has meant further changes. At the congress in 2011, the Brotherhood Movement changed its name to Social Democrats for Faith and Solidarity (Socialdemokrater för Tro och Solidaritet). They also redefined the organization from being solely Christian to including members from various religions, including Muslims and Jews, with believers in Ásatrú also welcomed (Svenska Dagbladet 2010; Broderskapsrörelsen, press release 2011).

\section{Reasons for Cooperation}

The Brotherhood Movement justifies cooperation with SMR by stressing the importance of dialogue. A recurring argument is that Muslim communities face a similar problem to that which the Christian Social Democrats faced before their organization was founded, namely that of finding a satisfactory way of joining their faith with other forms of societal commitments. A further argument is that dialogue may counter social exclusion (Weiderud 2006). It is seen as taking a risk not to engage in dialogue with Muslim organizations because of ideological differences, lest both Islamic extremism and Islamophobia gain a foothold instead (Weiderud 2009).

The Brotherhood Movement's collaboration with SMR has been criticized, for example, in a television programme specializing in investigative journalism on national TV (SVT: Uppdrag granskning 2006). Critics have wondered who SMR really represents, and have criticized the Council's ideological positions (Bergsten 2006). Representatives of the Brotherhood Movement have repeatedly argued that there are some 100,000 active Muslims in Sweden and that SMR represents 75,000 of them, figures clearly 
taken from statistics of the SST. According to this logic, SMR has a strong mandate. Further, representatives from the Brotherhood Movement claim to be collaborating with several different Muslim organizations, but a review of the members' magazine Brotherhood (1994-2004) shows that $80 \%$ of the articles on Islamic bodies are about the SMR (Bergsten 2006).

SMR's ideology has been rightly described as moderate Islamist, influenced by the Muslim Brotherhood ${ }^{5}$ (Carlbom 2006; Roald 2002). Using Mandaville's (2007) categorization of socio-political trends among Europe's Muslims, SMR can be described as 'communitarianist'. These tend to be politically pragmatic, while still having religious ideals as normative standards for their political work. They usually have a strong commitment to issues relating to (minority) rights of Muslims, and they tend to seek cooperation with and support from parties in the political mainstream.

The Brotherhood Movement claims that it does not accept extremism, but sees it as its task to bridge gaps between different religious communities. They believe that the necessary political dialogue with advocates of political Islam has been neglected. The reason is a fear of the religion itself, which has evolved into a fear of being associated with political Islam. Only through serious dialogue will it be possible to understand the wide range of positions within political Islam (Weiderud 2005).

The Brotherhood Movement's attitude can be interpreted as an attempt to help create a European version of Islam that will fit into existing structures. A tendency among political parties in the middle or to the left is to try to reshape Islam to make the religion fit their own political ideologies (Zemni 2002). Muslims are expected to accept and make use of existing structures in order to get access to social and political influence (cf. Fetzer \& Soper 2005; Silvestri 2007). According to Silvestri (2007), it is common

\footnotetext{
${ }^{5}$ The Muslim Brotherhood was founded in 1928 in Egypt, and is currently active in several countries with different orientations. The Brotherhood developed in the mid-1900s to a political, anti-imperialist movement in the Muslim world. Islam is perceived as a complete way of life, which includes a political commitment, see Eickelman \& Piscatori 1996.
} 
among European politicians to try to create national Muslim councils, set up to be the official representatives of Muslims. The state supports so-called moderate forms of Islam, which are considered to be in the interest of Muslims (Silvestri 2010). Bonnefoy (2003) argues that there is a demand among political parties and governments to distinguish between 'good' and 'bad' Islam. Good Islam is defined as moderate and the opposite of political Islam, the bad form. The official political discourse endeavours to delegitimize forms of Islam not viewed as accommodating. By doing so politicians and public institutions take it upon themselves to define what should be acceptable interpretations of Islam. According to Bonnefoy, this understanding is based on essentialist conceptions where religion exists decoupled from its adherents' often very different social practices.

In line with the above, the Brotherhood Movement states that its cooperation with Muslim groups will counter radicalization, thus promoting good Islam. In connection with the national election of 1998, representatives of the Brotherhood Movement wrote an article in the Islamic journal Salaam together with Muslims from SMR (Sahlberg et al. 1998). The collaboration was presented as an attempt to create 'political integration' through education about politics and democracy, and specific courses on social democratic party politics. We discern two main reasons: firstly, to educate 'Muslims' who are interested in politics, secondly, to attract new voters and school them into the Social Democratic Party. The writers mention issues they find to be of special importance to Muslims, and write 'in Muslim culture, religion is not just a cultural affiliation but accommodates a wide range of traditions and beliefs that affect all aspects of life' (Sahlberg et al. 1998:31, our translation). For example, Islam is considered to govern Muslims' views on the role of families and the relationships between men and women. The claim that religion (or Muslim culture) governs all aspects of the lives of Muslims is a recurring stereotype (also among the revivalist Muslim writers in Salaam, see Otterbeck 2000). Terms such as 'Islam' or 'Muslim culture' are notoriously vague. Which Muslims are referred to? Whose interpretation? Actual Muslim diversity is not addressed. Instead, the writers argue that today's society is highly individualized, while 
for Muslims it is 'important what the group does, and what the Imam (the Muslim leader) says' (Sahlberg et al. 1998:31, our translation).

The depictions of Muslims by the Brotherhood Movement often return to the idea that Muslims can be described as a group with certain needs that must be met, precisely on the grounds that they are Muslims (cf. Allievi 2003; Maussen 2007). It is assumed that active citizenship is intimately linked with the religious identity, and that it is through an emphasis on that identity that Muslims can articulate and defend their interests.

\section{Muslim Social Democrats in Search of a Voice}

Before the 2010 Swedish general election the Brotherhood Movement intensified its efforts to win Muslim votes. Part of this effort was to produce the magazine Islam and Politics (Islam och Politik), whose first edition was released during the month of Ramadan in 50,000 copies. Behind the magazine was the Brotherhood's Network for Progressive Muslims. The point of departure, according to the publisher, was that

there is a need for a progressive Muslim magazine in Sweden. There is still no channel for debate on Islam and politics, no daily or weekly newspaper, radio or television channel that concerns the daily lives of Swedish Muslims, or raises Islamic issues in a respectful manner and that can promote this perspective. (Vänster 2010, our translation)

The magazine mixes opinion-oriented material with columns and interviews. In the first issue, the editorial stresses that discussions about Muslims in Sweden too often address peripheral questions like the handshake debate, ${ }^{6}$ Lars Vilks' cartoons ${ }^{7}$ and the potential

\footnotetext{
${ }^{6}$ This debate revolved around a Muslim man who refused to shake the hand of a female employer, when he was applying for a job as a trainee at a factory. The employment office decided to suspend the man from the work programme he was involved in due to this. He was later awarded damages due to unlawful discrimination.

${ }^{7}$ Lars Vilks is an artist and art theoretician specializing in post-modern provocations against the taken for granted understanding of art. In 2007 he drew sketches of Muhammad combining the body of a dog with a turbaned head in a setting reminding Swedes of a spontaneous folk art expression at the time: the
} 
banning of the wearing of the burqa/niqab. These issues may have some significance, but the editorial stresses that there is a danger in that Muslims only get to voice views on marginal issues.

In the editorial, the Social Democratic Muslims present themselves as a mainstream option. The editorial states that only extremist forces profit from the addressing of peripheral issues; both Islamic extremists and those who want to increase fear and Islamophobia and limit Muslims' rights are referred to as extremists (Habib et al. 2010). The magazine features a manifesto for Muslim Social Democrats. Muslim identity is defined in an inclusive manner and it stresses that identity is based on the understanding that 'faith, practice and culture are expressed in many forms and different people attach different meaning to why they call themselves Muslims' (Habib et al. 2010, our translation). The preference for Social Democracy, it is explained, is due to the party's ideas of a common social structure, which goes hand in hand with Islam's passion for fairness. A commitment to the Social Democratic Party is the best way to translate the Koran's message from words into action. The manifesto's demands include: the right to build mosques, halal food in schools, time off for Friday prayers and religious ceremonies, as well as the right for Muslim women to be treated well regardless of whether they wear the hijab or not.

The manifesto never mentions socialism as a fundamental ideology of the Social Democratic Party. Further, the manifesto differs from the Brotherhood Movement's own ideological programme. The Brotherhood Movment's programme stresses that the goal for equality includes a society free from superiority and subordination, and that inequalities based on class differences, ethnicity, religion, gender or sexual orientation cannot be tolerated ('Manifest för Kristen Vänster' 2010). In the Muslim manifesto the part about gender and sexual orientation is left out ('Manifest för Muslimska

roundabout dogs, often bright coloured wooden sculptures in the form of animals placed in roundabouts for the fun of it. Some perceived the drawings as mere provocations and others saw them as a test of the freedom of expression. Vilks has been threatened and attacked because of the sketches. 
Socialdemokrater' 2010). The chairman of the Brotherhood Movement explained the difference between the two manifestos by stating that different cultures are at different stages when it comes to issues like this (Weiderud 2010).

\section{Muslim Candidates in Political Parties}

A new phenomenon (a third phase of active citizenship) is that some people who primarily present themselves as Muslims have the ambition of actively engaging in established political parties. This may indicate a pronounced individual desire for political integration in society or possibly a collective integration strategy. Candidates with immigrant backgrounds always run the risk of becoming representatives or spokespersons for parts of the population perceived as the ethnic 'others'. They often become responsible for finding political solutions to potentially controversial issues. It is also common that they seek this role (Dahlstedt 2005). Politicians with a Muslim family background are often torn between their roles as individual politician, group representative, and expert on Muslims. One example is Mehmet Kaplan, a former leader of Sweden's Young Muslims (Sveriges Unga Muslimer), who is spokesperson of the Green Party on integration issues and an active believer. Still, Kaplan does not invoke his faith in his role as a politician. How, then, is the situation for those who engage themselves politically and publicly express that they are motivated by an Islamic sense of justice and by their Muslimness?

The issue of Muslim candidates running for parliament generated debates long before the parliamentary election in September 2010. There was one common denominator in mass media coverage and political criticism: accusations of Islamism. Islamism is presented as a single phenomenon that is completely inappropriate in Swedish politics, if not downright sinister (Cato 2012). This happens all over Europe (Glynn 2009). As we have shown above, Mahmoud Aldebe, the former head of SMR, had over the years gained experience from political work collaborating with both the Social Democrats and the Centre Party (Centerpartiet). As a minority rights activist he has penned several open letters since the 1980s calling for specific rights for Muslims. When Aldebe decided to become a candidate for the right-wing Centre Party, it led to immediate 
criticism from others in the Centre Party. Elisabeth Thand Ringqvist (2009) writes that Aldebe is a 'radical Islamist, and allying himself with the most fundamentalist [forces] we have in Sweden. There is no doubt that radical Islamists want to take power by means other than democratic (our translation).' She gave as an example of Aldebe's Islamism an open letter he wrote in 2006 in which he pleaded for the introduction of Sharia laws in Sweden. ${ }^{8}$ Furthermore, she criticized Aldebe because of his claim to represent Muslims in Sweden; Thand Ringqvist believed that his extremism would create suspicion against Muslims. Aldebe subsequently chose to withdraw his candidacy.

Abdirisak Waberi, who was the principal of a Muslim 'free school' (state-supported private school) and active in Muslim organizations on a national level, also faced criticism when he decided to become a candidate for the right-wing Moderate Party (Moderaterna). A critical party colleague argued that Waberi was an Islamist and questioned his attitude towards gender equality. Furthermore, she wanted to know which Muslims he really represented (Burda 2009). Waberi's successful campaign gave him a place in the Swedish parliament, where his credentials concerning democracy, equality between the sexes and his supposed support for Islamism continues to be a matter of debate, now addressed by members of the populist Sweden Democrats party (Sverigedemokraterna). Both Aledebe and Waberi suffered from being public figures before, because over time they had made normative statements about what Islam is and admittedly made conservative statements on family values and the roles of men and women, etc. The possibility of a development of their views or a compartmentalization of their views (common to religious people in secular societies) was not considered.

\footnotetext{
${ }^{8}$ Mahmoud Aldebe wrote an open letter asking for, among other things, the right to follow Islamic family law in matters of marriage and divorce. Aldebe had written several similar letters before that never caused any fuzz. Admittedly, he never called for Islamic family law as clearly before. The call for collective religious rights was clearly unacceptable in Swedish political discourse. Aldebe swiftly and publicly modified his position (cf. Roald 2009).
} 
The issue of Islam has also attracted attention among the leftist Social Democrats. MP Carina Hägg (2010) claims that the political parties have too little knowledge about extreme Islam, and that everyone has a responsibility to keep extremists away from political influence. The then Chairman of the Social Democratic Women in Sweden (Socialdemokraternas kvinnoförbund), Nalin Pekgul (2010), who is herself a Muslim of Kurdish origins, argued that a group of Islamists is working hard and using all means to win new adherents, which includes the infiltration of political parties. She contrasted her description of the Islamists with the majority of Muslims who do not let religion dominate their daily lives. Schiffauer (2006) notes that politicians often make a distinction between real Islam (religion) and Islamism (ideology). Furthermore, only Muslims who support this distinction (and are on the right side of it) are viewed as acceptable partners in the debate. Muslims who question the distinction are defined as Islamists and are viewed as partisan. This situation is obviously similar to Bonnefoy's distinction between good and bad Islam.

\section{Individual and Collective Political Projects}

The conception of tolerance of pluralistic liberal societies not only requires believers to recognize that they must reasonably reckon with the persistence of disagreement in their dealings with non-believers and members of other faiths. The same recognition is also required of unbelievers in their dealings with believers in a liberal political culture. (Habermas 2008:112)

Those who pursue an active citizenship motivated by either an Islamic sense of justice or the conviction that Muslims need representatives are doing so in a defining moment in Sweden's political history. Organizing religious lobbying on school issues or to be able to enjoy benefits already given to other religious groups, seems quite uncontroversial. Over time, Muslim organizations and civil society associations have acquired many partners, not least through the networks of SST, an important political opportunity structure for religious activist at large. In these contexts, Muslims have been able to pursue issues in line with the multiculturalism policy of the society and outside the attention of the media. Their work has led to reasonable, pragmatic solutions 
regarding imams in hospitals and prisons, Muslim cemeteries, and collaborations with the temperance movement, etc. (see Otterbeck 2004, 2010).

Over time, some Muslim activists have also become politically experienced. After the initial period of organizing, lobbying for minority rights, another option has opened up. Nowadays, we find Muslims wanting to participate in national (and local) politics within the framework of the established parties, but who, unlike Muslim politicians who do not emphasize their Muslim identity, still use Islamic language and claim to represent the interests of Muslims in Sweden. Some of them, like Mahmud Aldebe, have already cooperated with the established parties for decades. In connection with their ambition to become regular politicians, however, earlier statements and their theological preferences have been brought back to life and used against them. After years at the periphery of public attention seeking to create a space for Muslim minorities, these candidates have often written a lot and made statements that are far more gender-conservative (and Islamically theological) than is normal in Swedish political discourse (Hennel 2009; Olofsson 2006; Otterbeck 2000). Before, statements have been plausible since they have been understood, if read or heard at all, as coming from marginalized voices in a process of integration. When the opinions are reevaluated today as political manifestos, Muslim candidates are effectively made suspect. They are perceived as disloyal to the Swedish system with reference to their dual identity as Muslims and Swedish, and are frequently accused of being Islamists, a category possible to understand as another word for suspect and blameworthy. Those who have collaborated with them, as the Brotherhood Movement has and does, risk being criticized too.

The Brotherhood Movement's understanding of the cooperation is interesting. By looking at SMR as representative of the ordinary Muslim, the movement can justify the need to talk to SMR even if its agenda is not always in line with the politics of the movement. The Brotherhood Movement has been aware that it has tried to help Muslims by trying to shape and control SMR's engagement in a process. In this context, the Brotherhood Movement has followed a general trend of perceiving the diverse 
Muslim population as a social group possible to reach and help through their representatives. This pragmatic policy has legitimated the Muslim organizations not only as religious actors but also political ones. Compared with most other actors, the Brotherhood Movement has been proactive, helping Muslims to take initiatives like organizing themselves or starting a political magazine. Still, even while open to collaboration, the Brotherhood Movement has tried to reshape and channel Islamic active citizenship; after all, it is part of a political party.

When Muslims seek active citizenship, this has to be understood in relation to political opportunity structures in Sweden. Compared with, for example, Fetzer and Soper's (2005) study of Britain, France and Germany, it appears that Muslims in Sweden have had great possibilities for using existing structures for association-based political work (not least through SST) to organize nationally and engage in minority rights issues. However, to engage in the public sphere as a politically active citizen in the context of party politics is complicated if a Muslim motivates his or her political engagement religiously. The political ideology holding that politically engaged religious Muslims are Islamists and as such have nothing to contribute to Swedish society is predominant not only among those who are highly critical of Islam but also among those who chose to cooperate with Muslim organizations and individuals. The latter try to tame the beast, the former to exorcise it. Public Muslim active citizenship in Sweden is thus to a certain degree created by Swedish structures but is in the same time rejected as something atypical and problematic, a paradox that has to be addressed and examined in a democratic and multicultural society.

\section{References}

Aldebe, Mahmoud, 2009: "En kort illustrerad guide för att förstå muslimer”, in: Almizan-ma.blogspot.com. Accessed 12 February 2010. 
Allievi, Stefano, 2003: "Muslim and Politics", in: S. Allievi, F. Dassetto, B. Maréchal \& J. Nielsen (eds): Muslims in the Enlarged Europe: Religion and Society, Brill, Leiden.

Berggren, Henrik and Lars Trägårdh, 2006: Är svensken människa? Gemenskap och oberoende i det moderna Sverige, Nordstedt, Stockholm.

Bergsten, Henrik, 2006: "Socialdemokraternas oheliga röstfiske" on SVT webpage. www.svt.se/svt/jsp/Crosslink.jsp?d=46152\&a=582062\&lid=puff_581960\&lpos =extra_0. Accessed 24 August 2007.

Bonnefoy, Laurent, 2003: "Public Institutions and Islam: A New Stigmatization?" in: ISIM Newsletter, no. 13: 22-23.

Broderskapsrörelsen and SMR, 1999: "Delaktighet, identitet \& Integration - Rapport från gemensam projektgrupp", Rapport 4/99, from the association's congress in Örebro.

Broderskapsrörelsen, 2011, press release 19 June 2011.

Burda, Judit, 2009: “Göteborgsmoderaterna sviker demokratiska ideal när de nominerar en islamist", in: Newsmill, www.newsmill.se/artikel/2009/12/07/en-sevarddokumentar-pa-svt-i-gar-hot-eller-mojlighet. Accessed 14 February 2010.

Carlbom, Aje, 2006: "Mångkulturalismen och den politiska mobiliseringen av islam" in: U. Hedetoft, B. Pettersson \& L. Sturfelt (eds): Bortom stereotyperna, invandrare och integration i Sverige och Danmark, Makadam förlag, Stockholm.

Casanova, José, 2001: “Civil Society and Religion: Retrospective Reflections on Catholicism and Prospective reflections on Islam”, in: Social Research, 68, 4: 1041-1080.

Cato, Johan, 2012: När islam blev svenskt: Föreställningar om islam och muslimer $i$ svensk offentlig politik 1975-2010, Lund Studies in the History of Religions, vol. 33, Lund University, Lund.

Dahlstedt, Magnus, 2005: Reserverad demokrati, Boréa, Umeå.

Eickelman, Dale and James Piscatori, 1996: Muslim Politics, Princeton University Press, Princeton. 
Ekström, Sören, 2006: "Staten, trossamfunden och samhällets grundläggande värderingar - en bakgrund" in: SST (ed.): Samfunden och bidragen. Proprius, Stockholm.

Fetzer, Joel S. and J. Christopher Soper, 2005: Muslims and the State in Britain, France and Germany, Cambridge University Press, Cambridge.

FIFS, 2010, "Samarbete med myndigheter och departement", www.fifs.se/index.php?option=com_content \&task=view\&id=13\&Itemid=1 . Accessed 13 February 2010.

Glynn, Sarah, 2009: "Liberalizing Islam: Creating Brits of the Islamic Persuasion" in: R. Philips (ed.): Muslim Spaces of Hope: Geographies of Possibility in Britain and the West, Zed, London.

Habermas, Jürgen, 2008: Between Naturalism and Religion, Polity Press, Cambridge.

Habib, Abdulkader, Kaba, Adrian, Al Naher, Somar, Mahmood, Qaisar, 2010: "Det finns viktigare ämnen än burkor”. Islam och Politik, no. 1, p. 2.

Hennel, Lena, 2009: "Muslimsk politiker ifrågasatt", in: Svenska Dagbladet, 14 December 2009.

Hägg, Carina, 2010: "Hela kvinnoförbundet fördömer de muslimska extremisternas åsikter”, in: Newsmill, www.newsmill.se/artikel/2010/01/05/hela-kvinnofrbundet-st-r-bakom-f-rd-manden-av-extrema-muslimers-sikter. Accessed 14 February 2010.

Högfeldt, David, 2009: "Muslim i styrelsen mål för Broderskap”, in: Världen idag, 5 August 2009.

Johansson, Ola, 2006: "Väl förankrad dialog med muslimer", in: Tidningen Broderskap, 10 May 2006.

Lagerlöf Nilsson, Ulrika, and Petra Pauli, 2005: "När etnicitet och religion möter folkrörelsetradition: De förtroendevalda inom etniska och religiösa organisationer”, in: Makten och Mångfalden: Eliter och Etnicitet i Sverige, Fritzes, Stockholm.

Larsson, Göran and Åke Sander, 2007: Islam and Muslims in Sweden: Integration or Fragmentation? A Contextual Study, Lit, Berlin. 
Lindgren, Åke, 2008: "Folk i rörelser: Om nykterhetsrörelsen och andra folkrörelser i Sverige efter 1970" in: Å. Lindgren (ed.): Nykterhet i rörelse. Nykterhetens och nykterhetsrörelsens utveckling efter 1970, Sober, Stockholm.

Lundberg, Harald, 1988: Broderskapsrörelsen $(s)$ i svensk politik: studier rörande ståndpunkter och praktiskt politiskt handlande under åren 1930-1980, Sveriges Kristna Socialdemokraters förbund, cop., Stockholm.

Mandaville, Peter G., 2007: Global Political Islam, Routledge, New York.

“Manifest för Kristen Vänster”, 2010: http://kristenvanster.wordpress.com/manifest/. Accessed 4 April 2011.

"Manifest för Muslimska Socialdemokrater", 2010:

http://www.socialdemokraterna.se/Webben-for-alla/Arbetarrorelsen/Sveriges-

Kristna-Socialdemokrater---Broderskapsrorelsen/Om-oss/Muslimskasocialdemokrater/Manifest-for-muslimska-socialdemokrater/. Accessed 4 April 2011.

Maussen, Marcel, 2007: “The Governance of Islam in Western Europe: A State of the Art Report", in: International Migration, Integration and Social Cohesion (IMISCOE), Working papers. Working Paper No.16. June. Amsterdam.

Odmalm, Pontus, 2007: "Civil Society, Migrant Organisations and Political Parties: Theoretical Linkages and Applications to the Swedish Context" in: Journal of Ethnic and Migration Studies, 30, 3: 471-489.

Olofsson, Peter, 2006: "Med koranen i klassrummet" in: Ottar, No. 2: http://www.rfsu.se/sv/Sex-och-politik/Ottar/Ottar-arkivet/Ottar-2006/Ottar-nr2-2006/Med-koranen-i-klassrummet/. Accessed 4 April 2011.

Otterbeck, Jonas, 2010: "Sweden: Cooperation and Conflict" in: A. Triandafyllidou (ed.): Muslims in 21st Century Europe: Structural and Cultural Perspectives, Routledge, London.

Otterbeck, Jonas, 2004: “The Legal Status of Islamic Minorities in Sweden” in: R. Aluffi Beck-Pecoz \& G. Zincone (eds): The Legal Treatment of Islamic Minorities in Europe, Peeters, Leuven. 
Otterbeck, Jonas, 2000: Islam på svenska: Tidskriften Salaam och islams globalisering, Almqvist \& Wiksell International, Stockholm.

Otterbeck, Jonas, 1999: "Skolan, islam och muslimer” in: I. Svanberg \& D. Westerlund (eds): Blågul islam? Muslimer i Sverige, Nya Doxa, Nora.

Otterbeck, Jonas and Pieter Bevelander, 2006: Islamofobi: En studie av begreppet, ungdomars attityder och unga muslimers utsatthet, Forum för levande historia, Stockholm.

Pekgul, Nalin, 2010: "Vi demokrater måste mobilisera mot islamismen”, in: Newsmill, www.newsmill.se/artikel/2010/01/20/vi-demokrater-m-ste-mobilisera-motislamismen. Accessed 14 February 2010.

Proposition 1975:26: "Regeringens proposition om riktlinjer för invandrar- och minoritetspolitiken m.m." [Proposition no. 1975:26.] www.riksdagen.se/webbnav/?nid=37\&doktyp=prop\&rm=1975\&bet=26\&dok_i d=FY0326. Accessed 22 February 2010.

Roald, Anne Sofie, 2009: Muslimer i nya samhällen, Daidalos, Göteborg.

Roald, Anne Sofie, 2002: “From the People's Home to Multiculturalism: Muslims in Sweden", in: Y. Haddad (ed.): Muslims in the West: From Sojourners to Citizens, Oxford University Press, New York.

Roy, Olivier, 2004: Globalized Islam: The Search for a New Ummah, Colombia University Press, New York.

Sahlberg, P.A., C. Gustafsson \& O. Johansson, 1998: "Socialdemokraterna har ambitioner i frågor som gäller muslimer", in: Salaam, No. 2: 31.

Sandström, Robert, 2007: “Muslimer välkomnas", in: Tidningen Broderskap, 7 August 2007.

Schiffauer, Werner, 2006: "Enemies within the Gates: The Debate about the Citizenship of Muslims in Germany", in: T. Modood, A. Triandafyllidou, and R. ZapataBarrero (eds): Multiculturalism, Muslims and Citizenship: A European Approach, Routledge, London. 
Silvestri, Sara, 2007: "Muslim Institutions and Political Mobilisation”, in: S. Amghar, A. Boubekeur and M. Emerson (eds): European Islam: The Challenges for Public Policy and Society, CEPS/OSI, Brussels/Budapest.

Silvestri, Sara, 2010: "Public Policies towards Muslims and the Institutionalization of 'Moderate' Islam in Europe. Some Critical Reflections”, in: A. Triandafyllidou (ed.): Muslims in 21st Century Europe: Structural and Cultural Perspectives, Routledge, London.

SMR, 2010: “Kongress 2010”. in:

www.sverigesmuslimskarad.se/index.php?subpage=56. Accessed 10 February 2010.

SST, 2010: "Statistik över antalet betjänade". www.sst.a.se/statistik.4.7501238311cc6f12fa580005236.html. Accessed 9 February 2010.

SST, 2009: “SST:s årsbok 2009”.

http://www.sst.a.se/download/18.49955727139d0ce5f5d644c/1377188452216/ \%C3\%85rsbok+2009.pdf. Accessed 8 January 2014.

Statham, Paul, Ruud Koopmans, Marco Giugni and Florence Passy, 2005: "Resilient or Adaptable Islam? Multiculturalism, Religion and Migrants' Claims-Making for Group Demands in Britain, the Netherlands and France”, in: Ethnicities, 4, 4: 427-459.

Stoltz, Pauline, 2002: "Politisk solidaritet" in: P. de los Reyes, I. Molina and D. Mulinari (eds): Maktens (o)lika förklädnader. Kön, klass \& etnicitet $i$ det postkoloniala Sverige, Atlas, Stockholm.

Svenska Dagbladet, 2010: "Broderskap inte längre kristna”, Svenska Dagbladet, 25 November 2010.

Svenska Kyrkan, 2010: "Medlemsstatistik", www.svenskakyrkan.se/default.aspx $? i d=100243 \& d i d=332302$. Accessed 9 February 2010.

Thand Ringqvist, Elisabeth, 2009: “Islamister hör inte hemma i Centern”, in: Expressen, 7 October 2009. 
Uppdrag Granskning, 2006: The SVT programme, Uppdrag Granskning, broadcast two episodes on "Islam and Integration in Swedish Society" in April/May 2006.

Vänster, Kristen: 2010, “Sveriges första tidning för progressiva muslimer ute 18 augusti”, http://kristenvanster.wordpress.com/page/4/. Accessed 18 March 2011.

Voet, Rian, 1998: Feminism and Citizenship, Sage, London.

Weiderud, Peter, 2010: "Broderskap, muslimer och HBT". http://kristenvanster.wordpress.com/2010/12/26/broderskap-muslimer-ochhbt/. Accessed 4 April 2011.

Weiderud, Peter, 2009: "Islamofobin växer där man inte möter islam i vardagen”, in: Newsmill, $\quad$ www.newsmill.se/artike1/2009/11/30/islamofobin-vaxer-dar-maninte-moter-islam-i-vardagen. Accessed 13 February 2010.

Weiderud, Peter, 2006: “Dialogen är en tillgång för den kristna vänstern”, in: Tidningen Broderskap, 19 April 2006.

Weiderud, Peter, 2005: "Smutskasta inte Stockholms moské”, in: Expressen, 17 September 2005.

Zemni, Sami, 2002:'Islam, European Identity and the Limits of Multiculturalism", in: W. Shadid and P. van Koningsveld (eds): Religious Freedom and the Neutrality of the State: The Position of Islam in the European Union, Peeters, Leuven.

Yttrande till Jordbruksdepartementet, 2005: letter dated 30 September 2005 with the title: "Yttrande över Djurskyddsmyndighetens redovisning av regeringsuppdrag om religiös slakt från Judiska Centralrådet, Sveriges Muslimska Råd och Broderskapsrörelsen”. 